\title{
Detecting Nitrous Oxide in Complex Mixtures Using FTIR Spectroscopy: Silage Gas
}

\author{
Yongjing Zhao', Anthony S. Wexler1, Frank Hase'2, Yuee Pan'1, Frank M. Mitloehner³ \\ ${ }^{1}$ Air Quality Research Center, University of California-Davis, Davis, USA \\ ${ }^{2}$ Karlsruhe Institute of Technology, Institute of Meteorology and Climate Research, Eggenstein-Leopoldshafen, Germany \\ ${ }^{3}$ Department of Animal Science, University of California-Davis, Davis, USA \\ Email:yjzhao@ucdavis.edu
}

How to cite this paper: Zhao, Y., Wexler, A.S., Hase, F., Pan, Y. and Mitloehner, F.M. (2016) Detecting Nitrous Oxide in Complex Mixtures Using FTIR Spectroscopy: Silage Gas. Journal of Environmental Protection, 7, 1719-1729.

http://dx.doi.org/10.4236/jep.2016.712139

Received: October 5, 2016

Accepted: November 4, 2016

Published: November 7, 2016

Copyright $\odot 2016$ by authors and Scientific Research Publishing Inc. This work is licensed under the Creative Commons Attribution International License (CC BY 4.0).

http://creativecommons.org/licenses/by/4.0/

\begin{abstract}
Nitrous oxide $\left(\mathrm{N}_{2} \mathrm{O}\right)$ is a greenhouse gas with about 300 times the global warming potential (GWP) of carbon dioxide $\left(\mathrm{CO}_{2}\right)$. It is emitted from a wide range of sources and is responsible for about $6 \%$ of anthropogenic US greenhouse gas emissions. Analytical techniques are needed that can measure concentrations of $\mathrm{N}_{2} \mathrm{O}$ rapidly and inexpensively in sources that are also emitting other compounds that may interfere with the analytical process. In this work, we demonstrate the use of Fourier Transform Infrared (FTIR) spectroscopy to analyze $\mathrm{N}_{2} \mathrm{O}$ in the complex mixture of gases produced during the early phase of the silage making process. Silage gas samples were collected into Tedlar bags from the bucket silos during the first week of corn ensiling. A bag of the silage gas was analyzed using a Bruker FTIR spectrometer coupled with a long optical path length White Cell. First, $\mathrm{N}_{2} \mathrm{O}$ infrared absorption bands were identified in the FTIR spectra of the silage gas by comparing them to both standard $\mathrm{N}_{2} \mathrm{O}$ gas and simulated infrared spectra which confirmed that $\mathrm{N}_{2} \mathrm{O}$ was present in the silage gas. Then, $\mathrm{N}_{2} \mathrm{O}$ concentration in the silage gas was derived from the FTIR spectra using LINEFIT program. It was demonstrated that FTIR spectroscopy is a viable method for measuring $\mathrm{N}_{2} \mathrm{O}$ concentrations in the silage gas.
\end{abstract}

\section{Keywords}

Corn Silage, Nitrous Oxide, FTIR, LINEFIT

\section{Introduction}

Nitrous oxide $\left(\mathrm{N}_{2} \mathrm{O}\right)$ is an important long lived greenhouse gas (GHG) with a global warming potential (GWP) of 265 compared to carbon dioxide $\left(\mathrm{CO}_{2}\right)(\mathrm{GWP}=1)$ and methane $\left(\mathrm{CH}_{4}\right)(\mathrm{GWP}=28)$ [1]. Unlike $\mathrm{CO}_{2}$ and $\mathrm{CH}_{4}$, the inventory of $\mathrm{N}_{2} \mathrm{O}$ emissions 
remains largely uncertain because some of the $\mathrm{N}_{2} \mathrm{O}$ emission sources have not yet been systematically quantified, such as those from agricultural sources, landfills, and waste water treatment systems. More importantly, some $\mathrm{N}_{2} \mathrm{O}$ sources may not have even been discovered yet.

The California Global Warming Solutions Act of 2006 (AB 32) requires California to reduce its GHG emissions to 1990 levels by 2020 [2]. In order to achieve this goal, accurate GHG emission budgets are needed, in which an improved estimation of $\mathrm{N}_{2} \mathrm{O}$ emissions from California agriculture is essential. Various gas emissions, except for $\mathrm{N}_{2} \mathrm{O}$, from silage have been investigated by various laboratory and field experiments [3] [4] [5]. The $\mathrm{N}_{2} \mathrm{O}$ emissions from silage corn cropland, but not from the corn silage, have been estimated worldwide [6] [7] [8]. Wang and Burries monitored nitrogenous gases produced by silage in both field and laboratory silos using a mass spectrometer [9]. They reported a maximum $\mathrm{N}_{2} \mathrm{O}$ concentration of $4.35 \%$ in the farm silo gas at about 54 hours after ensiling. Because $\mathrm{N}_{2} \mathrm{O}$ and $\mathrm{CO}_{2}$ both have a mass of 44 , the $\mathrm{N}_{2} \mathrm{O}$ signals were obtained by differentiating them from $\mathrm{CO}_{2}$ peaks in the mass spectra, which may have introduced measurement uncertainty. Little information has become available on $\mathrm{N}_{2} \mathrm{O}$ produced by silage since the Wang and Burries measurements, because in the interim silage gases produced during the early phase of ensiling were studied mostly for toxicity [3]. Insufficient attention has been given to $\mathrm{N}_{2} \mathrm{O}$ as an important GHG gas emitted during the silage making process.

The present paper demonstrates that FTIR (Fourier Transform Infrared) spectroscopy can be used to measure $\mathrm{N}_{2} \mathrm{O}$ concentration in the complex mixture that comprises silage gas, because some of the $\mathrm{N}_{2} \mathrm{O}$ absorption peaks are isolated from other gas absorptions in the FTIR spectra. Since the FTIR spectroscopic technique has been used for real-time measurements of $\mathrm{N}_{2} \mathrm{O}$ and other gas species [10] [11], it is an excellent tool for real time monitoring of $\mathrm{N}_{2} \mathrm{O}$ in silage gas and may also be suitable for measuring $\mathrm{N}_{2} \mathrm{O}$ emissions in other anthropogenic emissions mixtures.

\section{Materials and Methods}

\subsection{Fourier Transform Infrared (FTIR) Spectrometer}

An FTIR spectrometer (Bruker Optics, Inc., Tensor 27, Germany) with spectral resolution of $1 \mathrm{~cm}^{-1}$ was used in the present study, which covers the spectral range from 850 to $7000 \mathrm{~cm}^{-1}$ with a mid-infrared (MIR) source, a $\mathrm{KBr}$ beam-splitter, and a Cryo-cooled MCT detector. A White Cell with variable optical path length between 3.2 - 64 meters and a volume of 16 liters was coupled to the FTIR spectrometer to increase gas absorptions in the White Cell.

\subsection{LINEFIT Program}

An instrumental line shape retrieval program, called LINEFIT, developed by Hase [12] at the Karlsruhe Institute of Technology in Germany was used to analyze the FTIR spectra to derive the gas concentrations inside the White Cell. The LINEFIT code is in wide use within the FTIR group of the NDACC (Network for Detection of Atmospheric 
Composition Change, http://www.ndsc.ncep.noaa.gov) and TCCON (Total Carbon Column Observing Network) [11] for the analysis of reference gas cell spectra recorded with high-resolution [13] [14], but has also been used for the analysis of spectra observed with low-resolution spectrometers [15].

\subsection{Laboratory Bucket Silos}

Various types of laboratory silos had been used for decades to simulate the conditions of large scale silos for different purposes [16] [17] and references therein]. Procedures to make corn silage in laboratory bucket silos and collect gas samples from the bucket silos have been described by Hafner et al. [5]. In summary, for this study, twelve kilograms of corn forage were manually compressed in 18.9-liter buckets. Excess gases produced in bucket silos were collected and filled 5-liter Tedlar bags (SKC-West Inc., Fullerton, CA) during the first week after ensiling. A bag of the silage gas was analyzed by the FTIR spectroscopy to investigate what compounds were present in the silage gas. Since the properties of the silage produced in the bucket silos were similar to typical values [5], the silage produced in the bucket silo was normal so the gas sample collected should be representative of the complex mixture that is silage gas.

\section{Results}

\subsection{FTIR Spectra of the Silage Gas and Verification of $\mathrm{N}_{2} \mathrm{O}$ Peaks}

Gas samples were analyzed with Bruker Tensor 27 FTIR spectrometer coupled with a long-path White Cell. When switching gas samples in the White Cell, the White Cell was flushed three times by alternatively evacuating the chamber down below $1 \mathrm{hPa}$ and filling with pure nitrogen $\left(\mathrm{N}_{2}\right)$ to $1013 \mathrm{hPa}$. When analyzing pure $\mathrm{N}_{2}$ and standard $\mathrm{N}_{2} \mathrm{O}$ gas samples, the White Cell was filled with either one to $1013 \mathrm{hPa}$. To analyze the silage gas, 5 liters of silage gas from one 5-liter Tedlar bag plus 11 liters of high purity $\mathrm{N}_{2}$ were added to the White Cell to bring the pressure up to $1013 \mathrm{hPa}$ in the 16-liter White Cell. The White Cell was operated at ambient pressure to prevent any contamination to gas samples due to possible leaks. Therefore, the air samples from the bucket silos had been diluted by a factor of 3.2 in the White Cell.

The optical path length of the White Cell was adjusted close to its maximum of 64 meters in order to maximize instrument sensitivity and therefore to detect weak absorption signals. First, the FTIR spectrum of the high purity $\mathrm{N}_{2}$ was recorded as background. Then, the FTIR spectrum of the silage gas plus $\mathrm{N}_{2}$ mixture was recorded. Significant $\mathrm{N}_{2} \mathrm{O}$ absorption peaks were found in the FTIR spectra of the silage gas. In order to confirm that $\mathrm{N}_{2} \mathrm{O}$ absorptions were identified correctly, the FTIR spectrum of a 5-ppm standard $\mathrm{N}_{2} \mathrm{O}$ gas was also recorded.

Figure 1 shows four spectra in the $1850-2850 \mathrm{~cm}^{-1}$ spectral region at $1 \mathrm{~cm}^{-1}$ spectral resolution: 1) FTIR spectrum of air samples from the bucket silo; 2) FTIR spectrum of 5-ppm standard $\mathrm{N}_{2} \mathrm{O}$ gas in $\mathrm{N}_{2}$ balance; 3) FTIR spectrum of pure $\mathrm{N}_{2}$; and 4) simulated spectrum of $\mathrm{N}_{2} \mathrm{O}, \mathrm{CO}_{2}, \mathrm{CO}$, and $\mathrm{H}_{2} \mathrm{O}$ gases generated by the LINEFIT program and $\mathrm{Hi}-$ tran 2008 spectral lines parameters [18]. The first three spectra in Figure 1 were measured 


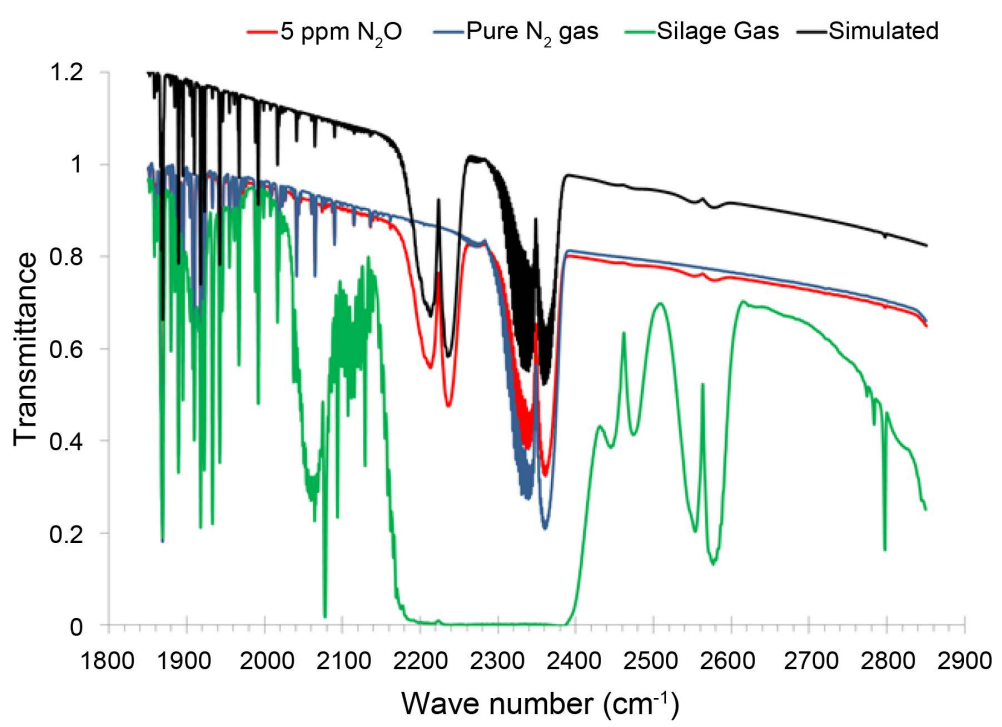

Figure 1. FTIR spectra of air samples from the bucket silos (green), 5-ppm standard $\mathrm{N}_{2} \mathrm{O}$ with $\mathrm{N}_{2}$ balance (red), and pure $\mathrm{N}_{2}$ gas (blue) in white cell recorded by a Bruker tensor FTIR spectrometer. A simulation spectrum of gases $\mathrm{N}_{2} \mathrm{O}, \mathrm{CO}_{2}, \mathrm{CO}$, and $\mathrm{H}_{2} \mathrm{O}$ by LINEFIT program is also shown (black) and upward shifted.

using the Bruker FTIR spectrometer coupled with a White Cell. The simulated spectrum takes into account not only the transmittance of all four gases but also the FTIR instrumental parameters.

The $\mathrm{N}_{2} \mathrm{O}$ absorption bands can be identified in the FTIR spectrum of the 5-ppm $\mathrm{N}_{2} \mathrm{O}$ standard gas and the simulation spectrum. The $\mathrm{N}_{2} \mathrm{O}$ absorption bands in the region of $2130-2270 \mathrm{~cm}^{-1}$ are the fundamental $v_{3}$ and associated "hot bands", which are strong absorptions [19]. The $\mathrm{N}_{2} \mathrm{O}$ absorption bands located between $2400-2600 \mathrm{~cm}^{-1}$ include a harmonic band of $2 v_{1}$ and a combination band of $v_{1}+2 v_{2}$ [20] which are relatively weak absorptions. These $\mathrm{N}_{2} \mathrm{O}$ absorption bands cannot be seen in the spectrum of the pure $\mathrm{N}_{2}$ gas. Figure 1 shows that the absorption of the silage gas in the region of 2130 $2270 \mathrm{~cm}^{-1}$ was saturated while the absorption of the 5-ppm $\mathrm{N}_{2} \mathrm{O}$ in the same region was not, indicating that the $\mathrm{N}_{2} \mathrm{O}$ concentration in the silage gas were much higher than 5 $\mathrm{ppm}$. On the other hand, the absorption of the silage gas in the region of $2400-2600$ $\mathrm{cm}^{-1}$ were not saturated and, by comparison, the absorption of the 5-ppm $\mathrm{N}_{2} \mathrm{O}$ gas in this region were much weaker, further confirming that $\mathrm{N}_{2} \mathrm{O}$ concentration in the bucket silos was much higher than $5 \mathrm{ppm}$.

A $\mathrm{CO}_{2}$ fundamental $v_{3}$ absorption band [21] located at $2349 \mathrm{~cm}^{-1}$ is shown in Figure 1 in the spectra of both the 5-ppm $\mathrm{N}_{2} \mathrm{O}$ gas and the pure $\mathrm{N}_{2}$ gas. Because $\mathrm{CO}_{2}$ should not be present in the White Cell in either case, this $\mathrm{CO}_{2}$ absorption came from $\mathrm{CO}_{2}$ gas outside the White Cell between 1) the FTIR MIR source and the White Cell, and 2) the White Cell and the FTIR MCT detector, because these two areas were exposed to ambient conditions. In the spectrum of the silage gas, the saturation between 2200 and $2400 \mathrm{~cm}^{-1}$ was due to the combined strong absorptions of $\mathrm{CO}_{2}$ and $\mathrm{N}_{2} \mathrm{O}$. The $\mathrm{CO}_{2} 3 v_{2}$ harmonic band at $2077 \mathrm{~cm}^{-1}$ is a weak absorption [21] that can be seen in the spectrum 
of the silage gas but not presented in the spectra of the 5-ppm $\mathrm{N}_{2} \mathrm{O}$ gas and the pure $\mathrm{N}_{2}$ gas.

\subsection{Retrievals of FTIR Spectra Using LINEFIT Program}

\subsubsection{Selection of the Spectral Windows}

The 5-ppm standard $\mathrm{N}_{2} \mathrm{O}$ spectrum in Figure 1 showed that 1 ) $\mathrm{N}_{2} \mathrm{O}$ absorption at the fundamental $v_{3}$ and associated "hot bands" was not saturated between 2130 and 2270 $\mathrm{cm}^{-1}$ and 2) the absorption of $\mathrm{CO}_{2}$ at the fundamental $v_{3}$ band located at $2349 \mathrm{~cm}^{-1}$ was not saturated either. Therefore, three spectral windows can be used to retrieve the 5-ppm $\mathrm{N}_{2} \mathrm{O}$ spectrum: i) $2140.0-2285.0 \mathrm{~cm}^{-1}$, ii) $2130.0-2650.0 \mathrm{~cm}^{-1}$, and iii) $2510.0-$ $2615.0 \mathrm{~cm}^{-1}$.

In the spectrum of the silage gas, two spectral windows at 2140 - 2615 and 2510 $2615 \mathrm{~cm}^{-1}$ were selected to retrieve the $\mathrm{N}_{2} \mathrm{O}$ concentrations. When fitting the spectral window at $2410-2615 \mathrm{~cm}^{-1}$, a special technique in the LINEFIT program, called "de-weighting", was applied to the sub-window between 2300 and $2510 \mathrm{~cm}^{-1}$ because of the complexity of $\mathrm{CO}_{2}$ absorptions in this region.

\subsubsection{Retrieval of FTIR Spectra of the 5-ppm Standard $\mathrm{N}_{2} \mathrm{O}$ Gas}

Retrieval of the 5-ppm $\mathrm{N}_{2} \mathrm{O}$ spectrum was to confirm that the selected spectral windows can be used to accurately derive the $\mathrm{N}_{2} \mathrm{O}$ gas concentrations from the FTIR spectra. The retrieval of the 5-ppm $\mathrm{N}_{2} \mathrm{O}$ spectrum was also used to calibrate the optical path length of the White Cell. The retrieval of FTIR spectra using the LINEFIT program does not need any calibration when the total columns (in $\mathrm{m}^{-2}$ ) of the species are derived, but in order to convert from total columns to gas concentrations, the optical path length of the White Cell is needed. Because it is difficult to accurately estimate the White cell's path length, calibration of the White Cell's optical path length was performed using the 5-ppm $\mathrm{N}_{2} \mathrm{O}$ standard gas mixture.

Figures 2-4 show the retrieval results of the 5-ppm $\mathrm{N}_{2} \mathrm{O}$ spectrum at three spectral windows. Both FTIR and fitted spectra are shown on the low portion of the figures in red and blue, respectively. The differences between FTIR and fitted spectra, called "Residuals", are shown on the upper portion of these figures. In principle, the LINEFIT program simulates a transmittance spectrum of all species at the given spectral window and fits it to the observed FTIR spectrum by scaling the total column of each species until the residuals fall in a preset threshold. The $\mathrm{N}_{2} \mathrm{O}$ columns in the White Cell along the optical path derived from the three spectral windows were $6.99 \times 10^{21}, 6.69 \times 10^{21}$, and $7.18 \times 10^{21} \mathrm{~m}^{-2}$, respectively. The optical path length of the White Cell was calibrated to be $57.6 \mathrm{~m}$. The converted $\mathrm{N}_{2} \mathrm{O}$ concentrations were 4.94, 4.91, and $5.08 \mathrm{ppm}$ respectively, which were $-1.2 \%,-1.8 \%$, and $1.7 \%$ different from the expected values of $5 \mathrm{ppm}$, resulting in an average of $4.98 \pm 0.09 \mathrm{ppm}$. The $\pm 0.09 \mathrm{ppm}$ error bar was the standard deviation of the retrieved values from the three spectral windows. Uncertainties caused by general spectroscopic error (line intensities and broadening coefficients) and experimental error (temperature, pressure, instrument line shapes, etc.) were not accounted in the error bar; these contribute less than $10 \%$ to the error estimate for 


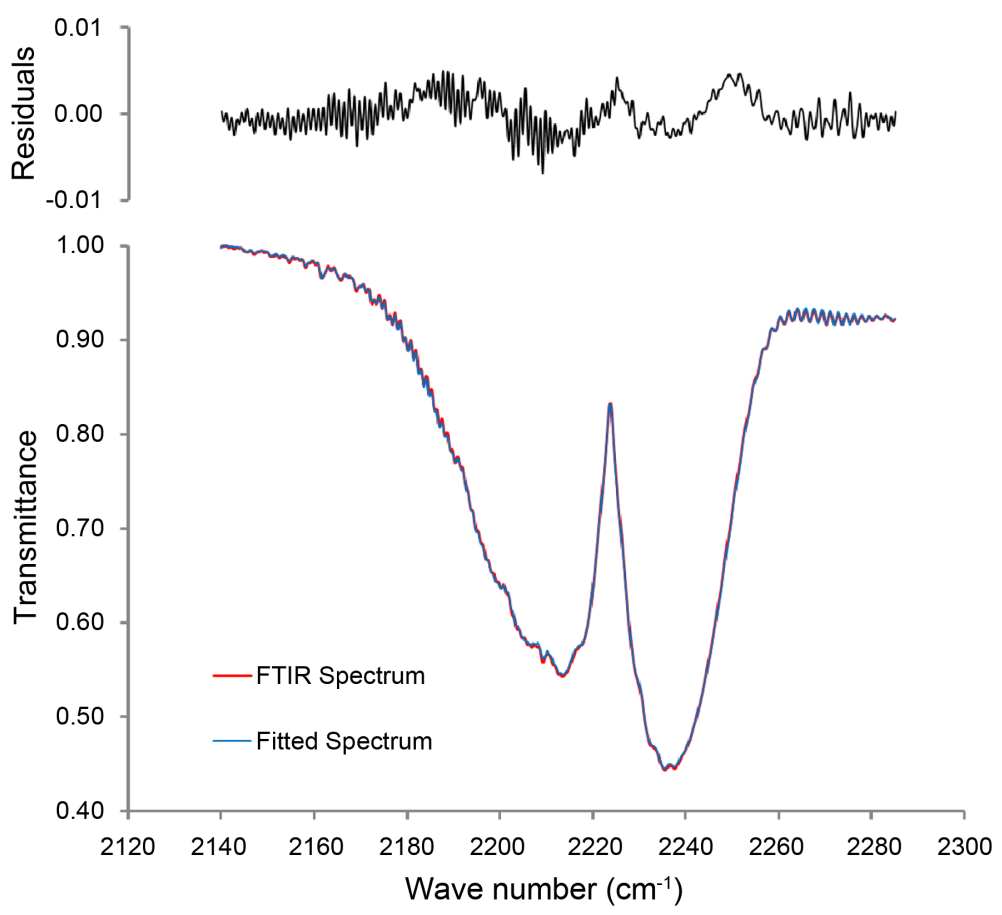

Figure 2. Retrieval of the 5-ppm $\mathrm{N}_{2} \mathrm{O}$ spectrum at window $2140-2285 \mathrm{~cm}^{-1}$. The FTIR spectrum (red) and the fitted spectrum (blue) are shown on the bottom panel. The differences between FTIR and fitted spectra (residuals) are shown in top panel in black.

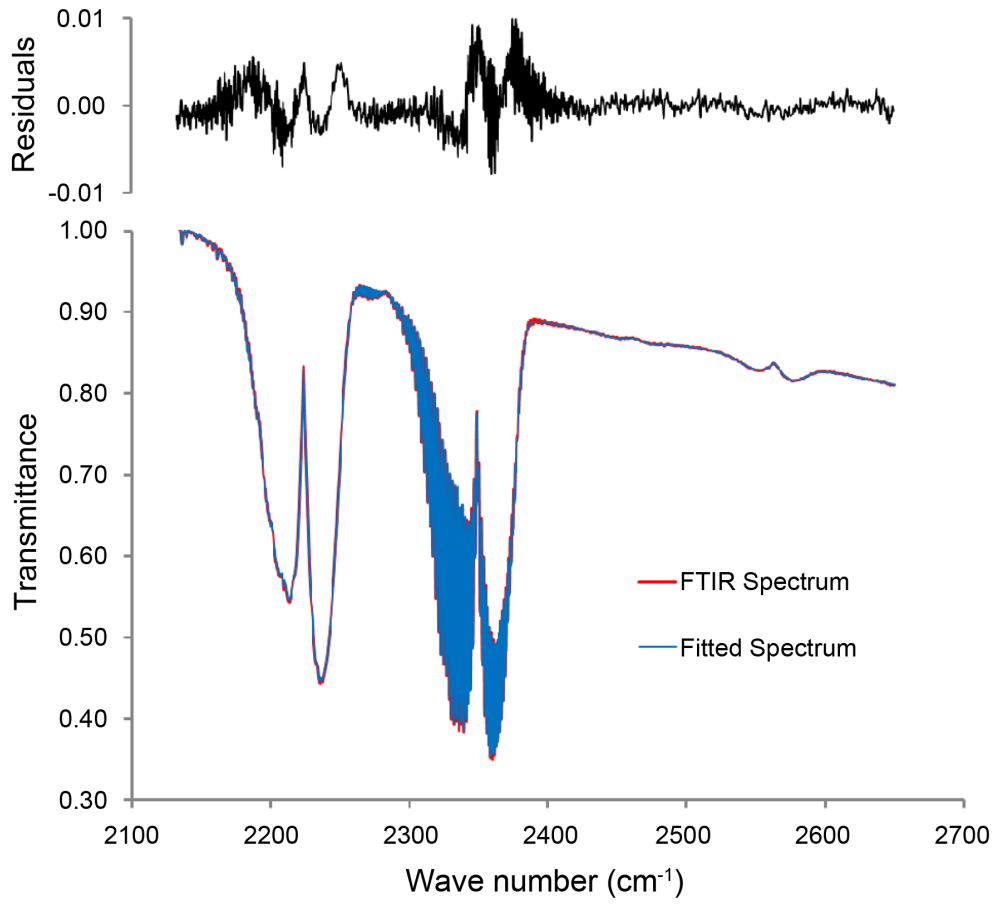

Figure 3. Same as Figure 2 except for window at $2140-2650 \mathrm{~cm}^{-1}$.

open-path FTIR measurements [22]. Similar uncertainty estimates apply to the error bars of the retrieval results in the rest of this paper so will not be repeated. 


\subsubsection{Retrieval of FTIR Spectra of the Silage Gas}

The $\mathrm{N}_{2} \mathrm{O}$ FTIR spectrum of the silage gas was retrieved at two spectral windows 2140 2615 and $2510-2615 \mathrm{~cm}^{-1}$. The spectral fitting results are shown in Figure 5 and Figure 6.

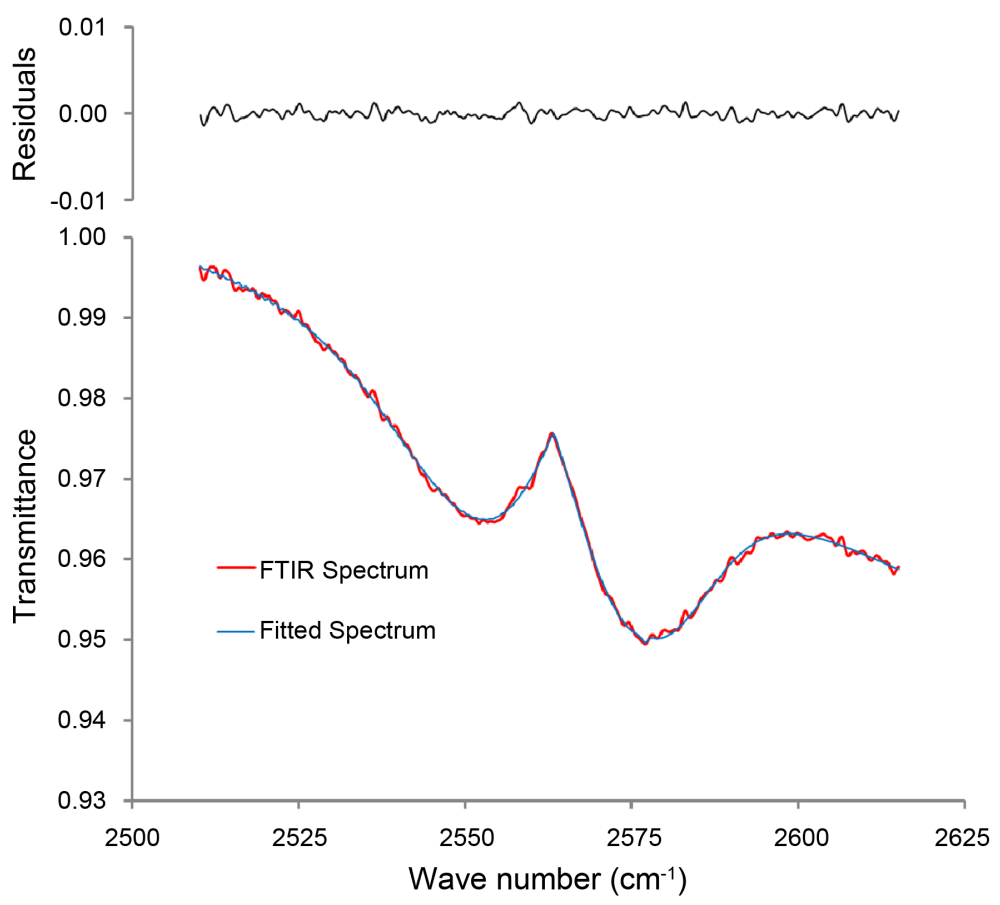

Figure 4. Same as Figure 2 except for window at $2510-2615 \mathrm{~cm}^{-1}$.

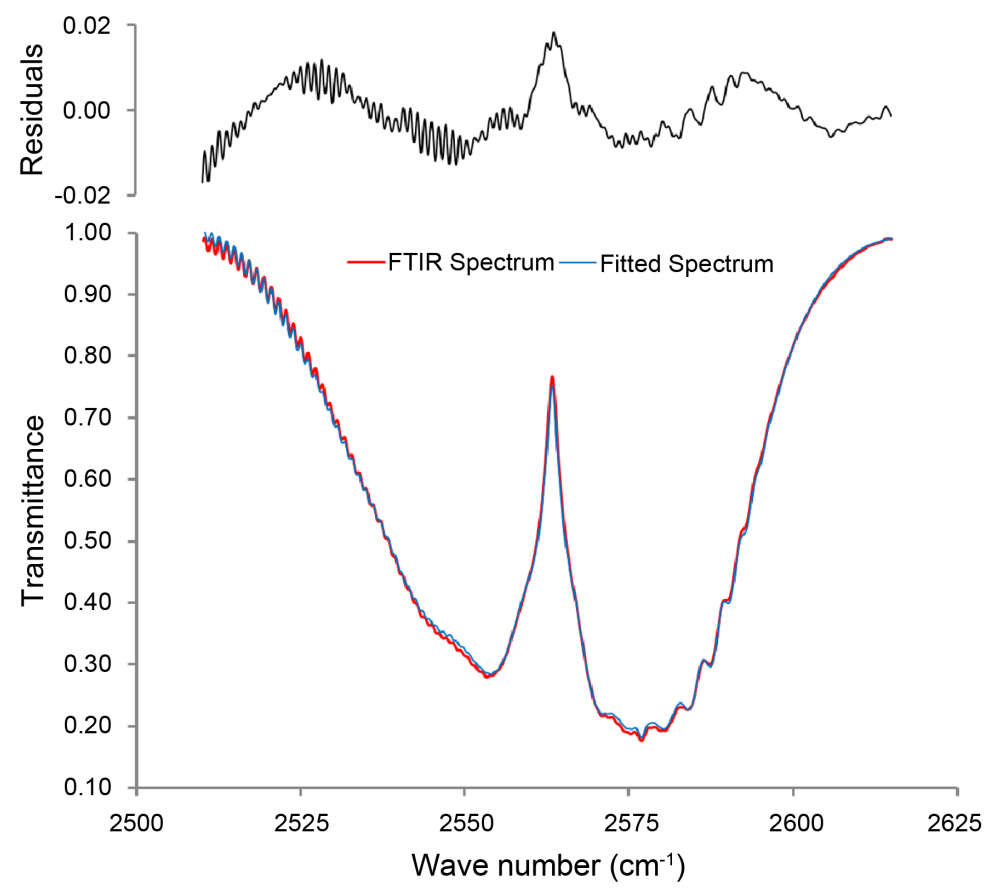

Figure 5. Retrieval of the bucket silos samples spectrum at window $2510-2615 \mathrm{~cm}^{-1}$. The FTIR spectrum (red) and the fitted spectrum (blue) are shown on the bottom panel. The differences between FTIR and fitted spectra (residuals) are shown in top panel in black. 


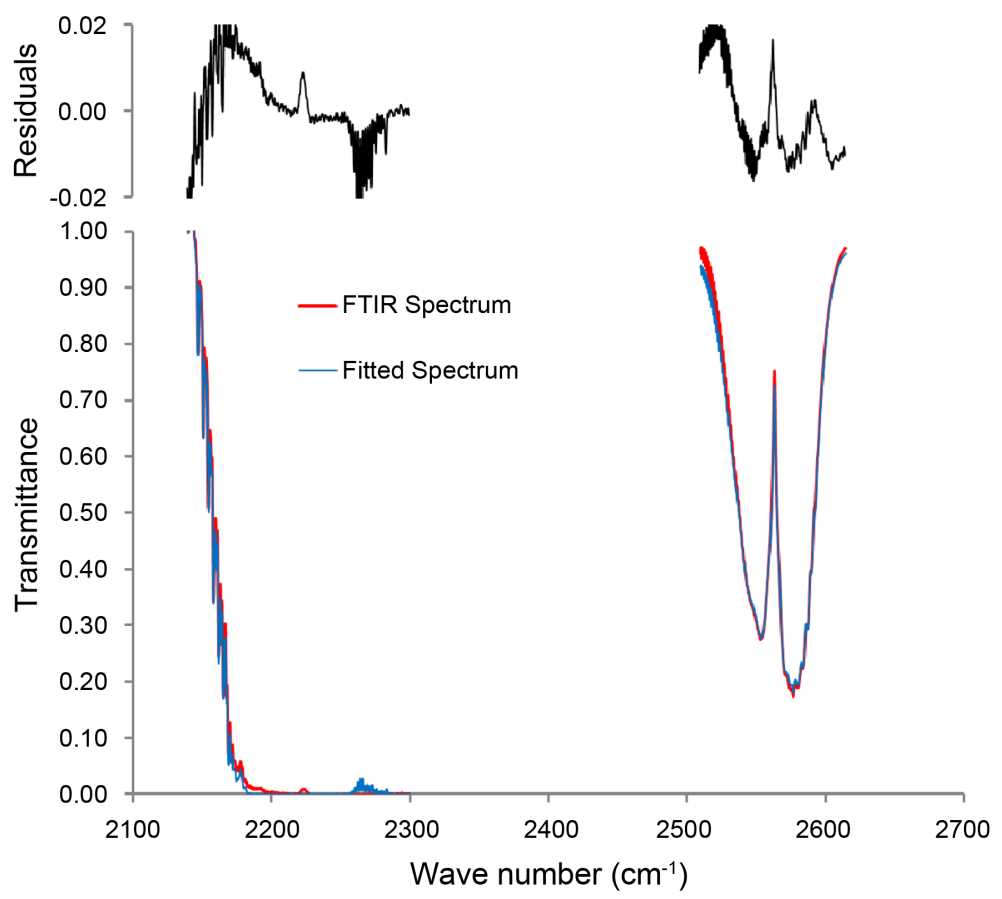

Figure 6. Same as Figure 5 except for at $2140-2615 \mathrm{~cm}^{-1}$ window with a sub-window at 2300 $2510 \mathrm{~cm}^{-1}$ de-weighted (not shown).

Similar to Figures 2-4, both FTIR and fitted spectra are shown on the low portion of the figures in red and blue, respectively. Their residuals are shown on the upper portion of the figures. In Figure 5, the $\mathrm{N}_{2} \mathrm{O}$ column in the White Cell retrieved from 2510 $2615 \mathrm{~cm}^{-1}$ window was $8.11 \times 10^{23} \mathrm{~m}^{-2}$, equivalent to $573.8 \mathrm{ppm} \mathrm{N}_{2} \mathrm{O}$ in the White Cell. Figure 6 shows the $2140-2615 \mathrm{~cm}^{-1}$ window without the $2300-2510 \mathrm{~cm}^{-1}$ sub-window because this region was de-weighted. In the de-weighting spectral regions, the LINEFIT program neglects the residuals between observed and simulated spectra in order for the residuals from other spectra regions to fall below the pre-set threshold. This technique is usually used when there is a particular absorption feature that the LINEFIT program cannot handle correctly. The $\mathrm{N}_{2} \mathrm{O}$ column in the White Cell retrieved from this window without the sub-window was $7.98 \times 10^{23} \mathrm{~m}^{-2}$, or $564.5 \mathrm{ppm}$. Because the $\mathrm{N}_{2} \mathrm{O}$ concentration in the Tedlar bag was diluted by a factor of 3.2 when the samples were introduced into the White Cell, the $\mathrm{N}_{2} \mathrm{O}$ concentrations in the silage gas are estimated to be 1836 and $1806 \mathrm{ppm}$, respectively, retrieved from the two spectral windows, resulting in an average of $1821 \pm 21 \mathrm{ppm}$. These two estimates agree within $1.7 \%$, similar to the uncertainty in retrieving concentrations from the 5-ppm $\mathrm{N}_{2} \mathrm{O}$ standard gas mixture spectrum.

\section{Discussion}

FTIR spectroscopy was used to analyze $\mathrm{N}_{2} \mathrm{O}$ in a complex gas mixture produced in corn silage. The corn silage was made in laboratory bucket silos and silage gas samples were collected during the early phase of ensiling. A 5-liter Tedlar bag of the silage gas was 
analyzed with a Bruker FTIR spectrometer at $1 \mathrm{~cm}^{-1}$ spectral resolution coupled with a long-path White Cell. $\mathrm{N}_{2} \mathrm{O}$ absorption peak fingerprints were identified in the FTIR spectra of the silage gas using both standard $\mathrm{N}_{2} \mathrm{O}$ gas spectra and simulated spectra from the IR spectral database. This observation verified that $\mathrm{N}_{2} \mathrm{O}$ was produced in the bucket silos at the early phase of ensiling. To quantify the $\mathrm{N}_{2} \mathrm{O}$ concentration, the FTIR spectra were retrieved using the LINEFIT program. $\mathrm{N}_{2} \mathrm{O}$ concentrations retrieved from three spectral regions of the 5-ppm $\mathrm{N}_{2} \mathrm{O}$ spectrum were $4.98 \pm 0.09 \mathrm{ppm}$ confirming that $\mathrm{N}_{2} \mathrm{O}$ can be accurately retrieved from FTIR spectra using LINEFIT program. An $\mathrm{N}_{2} \mathrm{O}$ concentration of $1821 \pm 21 \mathrm{ppm}$ was derived from two spectral regions of the silage gas FTIR spectra indicating that $\mathrm{N}_{2} \mathrm{O}$ concentration in the silage gas was very high. Wang and Burries [9] measured $\mathrm{N}_{2} \mathrm{O}$ concentrations in the farm silos using mass spectroscopy and reported that $\mathrm{N}_{2} \mathrm{O}$ varied from 10,000 to $43,500 \mathrm{ppm}$ in the first 66 hours and peaked at about 54 hours after ensiling, which was about 5.5 - 23.9 times greater than the $\mathrm{N}_{2} \mathrm{O}$ concentration in the laboratory bucket silos measured in the present study. The difference between the two measurements could be due to several factors: 1 ) $\mathrm{N}_{2} \mathrm{O}$ and $\mathrm{CO}_{2}$ both have a mass of 44 , so the $\mathrm{N}_{2} \mathrm{O}$ signals were obtained by differentiating them from $\mathrm{CO}_{2}$ peaks in the mass spectra, which might have introduced uncertainty in the mass spectroscopic measurements, 2) The differences in sampling locations and methods between the two measurements, and 3) The $\mathrm{N}_{2} \mathrm{O}$ concentrations between farm silos and laboratory bucket silos might be truly different.

\section{Conclusion}

The primary goal of this work was to 1 ) verify that $\mathrm{N}_{2} \mathrm{O}$ was present in silage gas during the early phase of ensiling based on FTIR spectroscopy, 2) demonstrate that $\mathrm{N}_{2} \mathrm{O}$ concentrations in silage gas can be accurately retrieved from FTIR spectra using the LINEFIT program, and 3) confirm that FTIR spectroscopy is a viable method for measuring $\mathrm{N}_{2} \mathrm{O}$ concentrations in complex gas mixtures, such as the silage gas. Since only one bag of silage gas was analyzed by FTIR for this study, the concentrations measured should be considered preliminary. Due to limited amounts of silage and silage gas sampled, the concentrations measured in this work should not be construed a quantitative estimate of $\mathrm{N}_{2} \mathrm{O}$ emissions from silages. In order to quantitatively investigate the $\mathrm{N}_{2} \mathrm{O}$ emissions from silage, an extended study is needed, including measurements of representative silage mixtures and ages of gas samples during silage making process. Most importantly, research is needed on methodology to reduce the $\mathrm{N}_{2} \mathrm{O}$ emissions during the silage making process. This work is intended as a pilot work to demonstrate the efficacy of using FTIR to measure $\mathrm{N}_{2} \mathrm{O}$ concentrations in complex mixtures such as emissions from silage.

\section{Acknowledgements}

This work was partly supported by California Air Resources Board (CARB) under research contract \#11-325 and the Academic Federation Professional Development Award 2015-2016 by University of California-Davis. Y. Z would like to thank the 
Karlsruhe Institute of Technology for hosting a 2-week visit.

\section{References}

[1] Myhre, G., et al. (2013) Anthropogenic and Natural Radiative Forcing. In: Stocker, T.F., Qin, D., Plattner, G.-K., Tignor, M., Allen, S.K., Boschung, J., Nauels, A., Xia, Y., Bex, V. and Midgley, P.M. Eds., Climate Change 2013: The Physical Science Basis. Contribution of Working Group I to the Fifth Assessment Report of the Intergovernmental Panel on Climate Change, Cambridge University Press, Cambridge, UK and New York, USA, p. 659.

[2] California Air Resources Board (CARB) (2006) California Global Warming Solutions Act of 2006 (AB32).

http://www.leginfo.ca.gov/pub/05-06/bill/asm/ab_0001-0050/ab_32_bill_20060927_chapter ed.pdf

[3] Reid, W.S., Turnbull, J.E., Sabourin, H.M. and Ihnat, M. (1984) Silo Gas: Production and detection. Canadian Agricultural Engineering, 25, 197-207.

[4] Hafner, S.D., Howard, C., Muck, R.E., Franco, R.B., Montes, F., Green, P.G., Mitloehner, F, Trabue, S.L. and Rotz, C.A. (2013) Emission of Volatile Organic Compounds from Silage: Compounds, Sources, and Implications. Atmospheric Environment, 77, 827-839. http://dx.doi.org/10.1016/j.atmosenv.2013.04.076

[5] Hafner, S.D., Franco, R.B., Kung Jr., L., Rotz, C.A. and Mitloehner, F. (2014) Potassium Sorbate Reduces Production of Ethanol and 2 Esters in Corn Silage. Journal of Dairy Sciences, 97, 7870-7878. http://dx.doi.org/10.3168/jds.2014-8537

[6] Linn, D.M. and Doran, J.W. (1984) Effect of Water-Filled Pore Space on Carbon Dioxide and Nitrous Oxide Production in Tilled and Nontilled Soils. Soil Science Society of America Journal, 48, 1267-1272. http://dx.doi.org/10.2136/sssaj1984.03615995004800060013x

[7] Van Groenigen, J.W., Kasper, G.J., Velthof, G.L., van den Pol-van Dasselaar, A. and Kuikman, P.J. (2004) Nitrous Oxide Emissions from Silage Maize Fields under Different Mineral Nitrogen Fertilizer and Slurry Applications. Plant and Soil, 263, 101-111. http://dx.doi.org/10.1023/B:PLSO.0000047729.43185.46

[8] Liu, C., Yao, Z., Wang, K. and Zheng, X. (2014) Three-Year Measurements of Nitrous Oxide Emissions from Cotton and Wheat-Maize Rotational Cropping Systems. Atmospheric Environment, 96, 201-208. http://dx.doi.org/10.1016/j.atmosenv.2014.07.040

[9] Wang, L.C. and Burries, R.H. (1960) Mass Spectrometric Study of Nitrogenous Gases Produced by Silage. Agricultural and Food Chemistry, 8, 239-242.

http://dx.doi.org/10.1021/jf60109a023

[10] Zhao, Y., Strong, K., Kondo, Y., Koike, M., Matsumi, Y., Irie, H., Rinsland, C.P., Jones, N. B., Suzuki, K., Nakajima, H., Nakane, H. and Murata, I. (2002) Spectroscopic Measurements of Tropospheric $\mathrm{CO}, \mathrm{C}_{2} \mathrm{H}_{6}, \mathrm{C}_{2} \mathrm{H}_{2}$, and $\mathrm{HCN}$ in Northern Japan. Journal of Geophysical Research: Atmospheres, 107, ACH 2-1-ACH 2-16.

http://dx.doi.org/10.1029/2001jd000748

[11] Wunch, D., Taylor, J.R., Bernath, D. Fu, P., Drummond, J.R., Midwinter, C., Strong, K. and Walker, K.A. (2007) Simultaneous Ground-Based Observations of $\mathrm{O}_{3}, \mathrm{HCl}, \mathrm{N}_{2} \mathrm{O}$, and $\mathrm{CH}_{4}$ over Toronto, Canada by Three Fourier Transform Spectrometers with Different Resolutions. Atmospheric Chemistry and Physics, 7, 1275-1292.

http://dx.doi.org/10.5194/acp-7-1275-2007

[12] Hase, F., Blumenstock, T. and Paton-Walsh, C. (1999) Analysis of the Instrumental Line Shape of High-Resolution Fourier Transform IR Spectrometers with Gas Cell Measurements and New Retrieval Software. Applied Optics, 38, 3417-3422. 
http://dx.doi.org/10.1364/AO.38.003417

[13] Hase, F. (2012) Improved Instrumental Line Shape Monitoring for the Ground-Based, High-Resolution FTIR Spectrometers of the Network for the Detection of Atmospheric Composition Change. Atmospheric Measurement Techniques, 5, 603-610. http://dx.doi.org/10.5194/amt-5-603-2012

[14] Hase, F., Drouin, B.J., Roehl, C.M., Toon, G.C., Wennberg, P.O., Wunch, D., Blumenstock, T., Desmet, F., Feist, D.G., Heikkinen, P., De Mazière, M., Rettinger, M., Robinson, J., Schneider, M., Sherlock, V., Sussmann, R., Té, Y., Warneke, T. and Weinzierl, C. (2013) Calibration of Sealed $\mathrm{HCl}$ Cells Used for TCCON Instrumental Line Shape Monitoring. Atmospheric Measurement Techniques, 6, 3527-3537. http://dx.doi.org/10.5194/amt-6-3527-2013

[15] Frey, M., Hase, F., Blumenstock, T., Groß, J., Kiel, M., Mengistu Tsidu, G., Schäfer, K., Sha, M.K. and Orphal, J. (2015) Calibration and Instrumental Line Shape Characterization of a Set of Portable FTIR Spectrometers for Detecting Greenhouse Gas Emissions. Atmospheric Measurement Techniques, 8, 3047-3057. http://dx.doi.org/10.5194/amt-8-3047-2015

[16] Neal, W.M. and Becker, R.B. (1933) A Type of Laboratory Silo and Its Use with Crotalaria. Journal of Agricultural Research, 47, 617-625.

[17] Johnson, H.E., Merry, R.J., Davies, D.R., Kell, D.B., Theodorou, M.K. and Griffith, G.W. (2005) Vacuum Packing: A Model System for Laboratory-Scale Silage Fermentations. Journal of Applied Microbiology, 98, 106-113. http://dx.doi.org/10.1111/j.1365-2672.2004.02444.x

[18] Rothman, L.S., et al. (2009) The HITRAN 2008 Molecular Spectroscopic Database. Journal of Quantitative Spectroscopy \&. Radiative Transfer, 110, 533-572. http://dx.doi.org/10.1016/j.jqsrt.2009.02.013

[19] Plyler, E.K., Tidwell, E.D. and Maki, A.G. (1964) Infrared Absorption Spectrum of Nitrous Oxide $\left(\mathrm{N}_{2} \mathrm{O}\right)$ From $1830 \mathrm{~cm}^{-1}$ to $2270 \mathrm{~cm}^{-1}$. Journal of Research of the National Bureau of Standards-A. Physics and Chemistry, 68A, 79-86. http://dx.doi.org/10.6028/jres.068A.006

[20] Plyler, E.K. and Barker, E.F. (1931) The Infrared Spectrum and the Molecular Configuration of $\mathrm{N}_{2} \mathrm{O}$. Physical Review, 38, 1827-1836. http://dx.doi.org/10.1103/PhysRev.38.1827

[21] Martin, P.E. and Barker, E.F. (1932) The Infrared Absorption Spectrum of Carbon Dioxide. Physical Review, 41, 219-303. http://dx.doi.org/10.1103/PhysRev.41.291

[22] Smith, T.E.L., Wooster, M.J., Tattaris, M. and Griffith, D.W.T. (2011) Absolute Accuracy and Sensitivity Analysis of OP-FTIR Retrievals of $\mathrm{CO}_{2}, \mathrm{CH}_{4}$ and $\mathrm{CO}$ over Concentrations Representative of "Clean Air" and "Polluted Plumes". Atmospheric Measurement Techniques, 4, 97-116. http://dx.doi.org/10.5194/amt-4-97-2011 
Submit or recommend next manuscript to SCIRP and we will provide best service for you:

Accepting pre-submission inquiries through Email, Facebook, LinkedIn, Twitter, etc. A wide selection of journals (inclusive of 9 subjects, more than 200 journals)

Providing 24-hour high-quality service

User-friendly online submission system

Fair and swift peer-review system

Efficient typesetting and proofreading procedure

Display of the result of downloads and visits, as well as the number of cited articles

Maximum dissemination of your research work

Submit your manuscript at: http://papersubmission.scirp.org/

Or contact jep@scirp.org 